\title{
Lower Ordovician cystoids (Rhombifera, Diploporita) from the Prague Basin (Czech Republic)
}

\author{
Michal MeRGL \& RUdOLF J. PROKOP
}

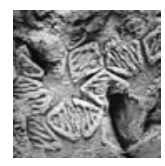

\begin{abstract}
Seven cystoid taxa, including one new species, are described or re-described from the Třenice and Mílina formations (Lower Ordovician, upper Tremadocian) of the Prague Basin: Macrocystella cf. greylingi, Echinosphaerites concomitans, E. sp., Glyptosphaerites ferrigena, Paleosphaeronites crateriformis, P. grossularia and Pyrocystites sp. New data on the morphology of Paleosphaeronites, i.e., gonoduct canal and palatal plates in peristome, are presented. A fixo-sessile mode of life of Paleosphaeronites is documented by the specimens attached to trilobite exoskeletons. The described cystoid fauna is one of the earliest yet known, and indicates remarkable echinoderm diversity and favourable marine environment in the late Tremadocian in the European part of peri-Gondwana region. • Key words: Cystoidea, Rhombifera, Diploporita, taxonomy, Tremadocian, Prague Basin, Bohemia, Czech Republic.
\end{abstract}

Mergl, M. \& PROKOP, J.R. 2006. Lower Ordovician cystoids (Rhombifera, Diploporita) from the Prague Basin (Czech Republic). Bulletin of Geosciences 81(1), 1-15 (10 figures). Czech Geological Survey, Prague. ISSN 1214-1119. Typescript received May 23, 2005; accepted in revised form January 12, 2006; issued March 31, 2006.

Michal Mergl, University of West Bohemia, Department of Biology, Klatovská 51, 30619 Plzeň, Czech Republic; mmergl@kbi.zcu.cz・Rudolf J. Prokop, National Museum, Department of Palaeontology, Václavské nám. 68,11579 Praha 1, Czech Republic; rudolf.prokop@nm.cz

Thecae and thecal plates of echinoderms belonging to the classes Rhombifera and Diploporita are locally common among more diversified fossil assemblages in the Třenice and Mílina formations (upper Tremadocian) of the Prague Basin. Considering that modern revisions of these groups have recently appeared in other European territories (Paul 1968, 1973, Paul \& Bockelie 1983, Bockelie 1984, Gutiérrez-Marco et al. 1996, Sdzuy et al. 2001), we expected that the description and critical revision of earlier data would be significant for incoming studies of the earliest Ordovician of the Mediterranean Realm. In the appendix, we comment upon the affinity of problematical subrectangular plates - reminiscent of carpoid plates and referred with doubt by Klouček (1918) to a polyplacophoran.

\section{Historical overview}

The earliest report on echinoderms from the Tremadocian of the Prague Basin was given by Barrande (1887). He described and figured two species under the generic name Echinosphaerites Wahlenberg, 1818: E.? concomitans Barrande, 1887 and E.? ferrigena Barrande, 1887. Both species are now represented by a few specimens housed in the collection of the National Museum in Prague. These are mostly imperfectly preserved in haematite, which was mined in the mid-nineteenth century in the "V Ouzkém" mine near Holoubkov, cca 70 km SW of Prague (in Barrande's original spelling: Ausker Zeche and Holoubka). The haematite ore, and its stratigraphic level near the base of the Ordovician sequence, have been repeatedly discussed since Lipold's (1863) paper. These haematites have recently been assigned to the upper Tremadocian Třenice Formation by Havlíček \& Vaněk (1966).

Since Barrande's time, only Růžička (1927) has described three other species (i.e., Sphaeronites crateriformis sp. nov., Sphaeronites batheri sp. nov., and Sphaeronites sp.) from the same locality, though his descriptions and illustrations are poor. Prokop (1964) critically revised the description of these cystoids, and grouped them into a single species of the new genus Paleosphaeronites.

The cystoids from the overlying Mílina Formation have never been formally described. However, their presence was reported in the earliest paper describing a rich fauna of the Mílina Formation (Klouček 1914). Some of the original labels attached to specimens stored in the National Museum enabled correlation with the names used in Klouček's fossil list (1917).

Mergl (1984) referred formerly collected specimens, as well as his new finds, to the genera Glyptosphaerites Müller, 1854 and Paleosphaeronites Prokop, 1964, but without formal description or illustration. He also confirmed the presence of Macrocystella Callaway, 1877 in the Mílina Formation. Data about echinoderms of late Tremadocian age were 


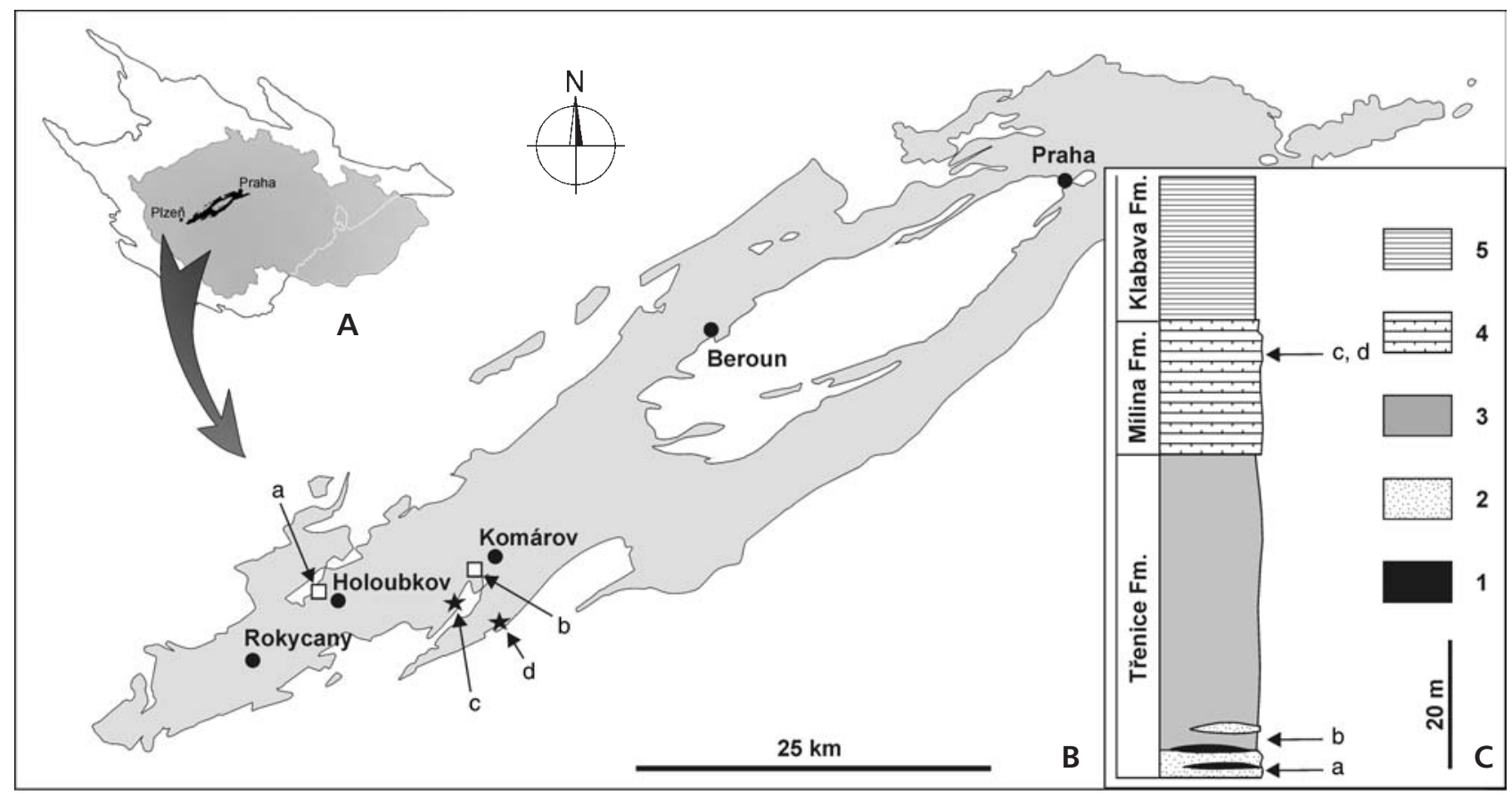

Figure 1. A - schematic map showing the location of the Bohemian Massif, the Czech Republic and the Prague Basin. $\bullet$ B - geographic distribution of the Ordovician strata in the Prague Basin with localities bearing the cystoid fauna of the Třenice (rectangles) and Mílina (stars) formations: a Holoubkov, "V Ouzkém", b - Jivina, slope debris, c - Olešná, quarry, d - Horní Kvaň. • C - generalized stratigraphic section with marked level of the cystoid fauna (only basal part of the Klabava Formation is shown), letters as in Fig. 1B: 1 - haematite, 2 - conglomerate, 3 - greywacke, 4 - chert, 5 siltstone.

briefly summarised by Prokop \& Petr (1999) in a checklist of echinoderms of the Bohemian Ordovician.

\section{Stratigraphic distribution}

The earliest Bohemian Ordovician cystoids are known from the upper Tremadocian Třenice and Mílina formations. The transgressive Třenice Formation consists of conglomerates and sandstones, with local siltstone beds. Some conglomerates have haematite cement. The layers of haematite ores, however, are rare and confined to only a few local sites. The thickness of the formation may reach cca 70 metres in the Komárov area, but it is generally smaller. Cystoids are known exclusively from the lowest parts of the formation, where the haematite and coarse greywacke beds are present. Echinosphaerites concomitans Barrande, 1884, Glyptosphaerites ferrigena (Barrande, 1887) and Paleosphaeronites crateriformis (Růžička, 1927) were sampled from this formation.

The overlying Mílina Formation consists of chert, sandstone, and siltstone beds, commonly reddish in colour. The formation has a regressive character according to Kettner (1921), but in some parts of the basin it is transgressive (for instance in the area between Strašice and Zaječov). The maximum thickness of the formation is about $20 \mathrm{~m}$. Cystoids were collected from several beds of reddish chert in the upper part of the formation. Macrocystella cf. greylingi Hammann \& Sdzuy, 2001, Echinosphaerites sp., Paleosphaeronites grossularia sp. nov. and Pyrocystites sp. are known from this formation.

Havlíček \& Vaněk (1966) suggested early Tremadocian age for the Třenice Formation and late Tremadocian age for the Mílina Formation, but new unpublished observations indicate that both formations are more likely of late Tremadocian age.

\section{Localities and material}

1. Holoubkov, abandoned iron ore mine called "V Ouzkém", massive haematites from old dumps. Třenice Formation, lower part (Fig. 1). Material collected by J. Barrande and his collectors, C. Klouček, R. Růžička, and one of the present authors (MM).

2. Jívina, slope debris near the Jivína-Komárov road, coarse grained greywacke. Třenice Formation, lower part (Fig. 1). Material collected by one of the present authors (MM).

3. Olešná, an old quarry east of the village, red and white limonitic chert. Mílina Formation, upper part (Fig. 1). Material collected by C. Klouček and one of the present authors (MM). 4. Horní Kvaň, slope debris on a low ridge south of the village. Mílina Formation, upper part (Fig. 1). Material collected by one of the present authors (MM). 


\section{Mode of preservation}

Although the cystoids are relatively common in some fossil assemblages of the Třenice and Mílina formations, their quality and mode of preservation vary depending on the sediments. The best preserved thecae are derived from the massive haematite ores developed as irregular thin lenses near the base of the Třenice Formation. The specimens are known only from the dumps of the "V Ouzkém" ("Ouzký") iron ore mine near Holoubkov, which has been abandoned for more than 150 years. All fossils at that locality have been distinctly affected by transport and sorting processes. Therefore, the cystoid thecae are generally fragmentary. Only small and rigid thecae are relatively complete. The preservation is unique due to the secondary silicification; although fine details of thecae are sometimes present, the calcitic thecal plates are totally replaced by crystalline quartz, and externally coated by a thin haematite film.

An apparently equivalent cystoid fauna, derived from a loose greywacke debris slope near the base of the Třenice Formation, was found in the area between Jivina and Komárov. A coarsely grained rock preserved only imperfect external and internal moulds lacking any details apart from general subglobose thecal shape.

The preservation of cystoids is different in the Milina Formation. Thecae are preserved mostly as internal and external moulds in the thin-bedded red-brown chert layers. Originally calcitic plates were dissolved and replaced by a secondary quartzose or limonitic matrix that fills the hollows. The cavities inside the thecae are sometimes filled by scalenohedronic crystals, originally of calcite but also replaced by quartz. The fine morphological details are generally lacking, but internal moulds and mineral infillings of pores are preserved.

\section{Synecology}

Cystoids of the Třenice Formation are associated with a diverse benthic fauna, mainly brachiopods and trilobites. The faunal diversity is remarkably high, with some twenty species of brachiopods, typically dominated by Poramborthis, Kvania, Apheoorthina, Eoorthis, and Jivinella (Havlíček 1977, 1982, Mergl 2002). Twelve trilobite species, predominated by the genera Holubaspis, Holoubkocheilus, Parapilekia, and Hemibarrandia (Mergl 1994), are associated with these cystoids. The clisospirid gastropod Mimospira and sponge spicules are very rare (Růžička 1927).

The cystoids of the Mílina Formation are associated with taxonomically related successive faunas. Among the brachiopods the genera Jivinella, Kvania, and Poramborthis are the most significant (Havlíček 1977, 1982), together with abundant lingulate brachiopods such as Thysanotos (Mergl 2002), and siliceous sponges. A diverse trilobite

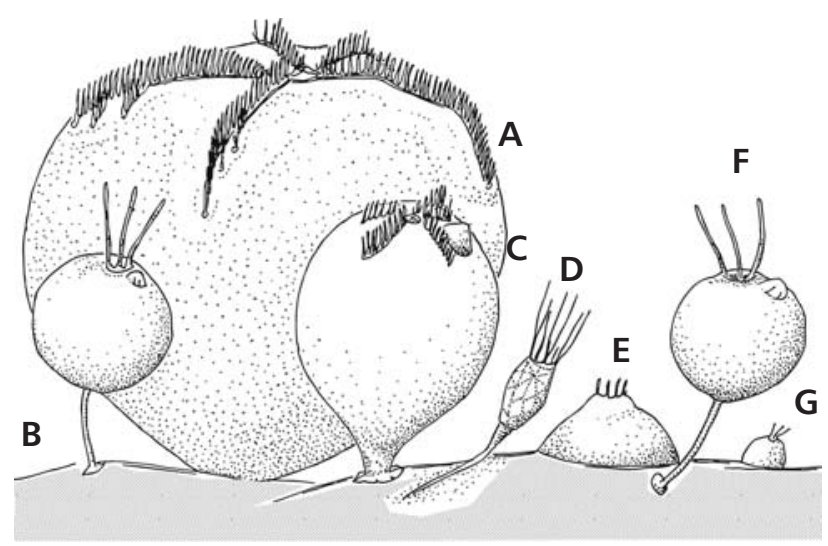

Figure 2. Relative size and suggested mode of attachment of the cystoids of the upper Tremadocian of the Prague Basin. - A - Glyptosphaerites ferrigena (Barrande, 1887). • B - Echinosphaerites concomitans Barrande, 1887. • C - Pyrocystites sp. • D - Macrocystella cf. greylingi Hammann \& Sdzuy, 2001. • E - Paleosphaeronites crateriformis (Růžička, 1924). • F Echinosphaerites sp. • G - Paleosphaeronites grossularia sp. nov. Firm substrate is grey, sandy substrate is stippled. Half the original size.

fauna, including Holubaspis, Parapilekia, Hemibarrandia, Harpides, Orometopus (Mergl 1984), and other rare fossils, is present in three localities in the Komárov area (Mergl 1984). A shallow littoral environment affected by currents and hydrodynamic sorting processes is suggested in all sites with rich fauna.

\section{Autecology}

The mode of life of Echinosphaerites was discussed by Bockelie (1981). The Baltic species had a subtle attachment stem indicating a sedentary mode of life. The same patterns can be assumed for Echinosphaerites concomitans and possibly also for Echinosphaerites sp. In Glyptosphaerites ferrigena, the stem was present at least in immature individuals. The adult specimens were very large and were probably loosely lying on the bottom or anchored by a small stem; two minute columnals observed in the material may belong to these genera (Fig. 10F). In Pyrocystites sp. the base of theca is extended into a short conical stalk, which was directly attached to the substrate. Regular circles of eight or nine thick plates are known from the Třenice and Mílina formations (Prokop 1964); these may represent an attachment disc of a large reversely pyriform theca.

The shape of the original material of $P$. crateriformis from the Třenice Formation led Prokop (1964) to suggest the possible direct fixation of the thecal base to a hard substrate. Although numerous specimens were observed, none of them has been found attached directly to other fossils or to the surfaces of associated pebbles. However, three specimens from the Mílina Formation were found attached to trilobite exoskeletons, and in one sample two 
equally-sized specimens are cemented (Fig. 8H) to the side of the glabella of a large cheirurid trilobite Parapilekia olesnaensis (Růžička, 1935). Another specimen is attached to the internal surface of the pygidium of a large illaenid trilobite Hemibarrandia holoubkovensis (Růžička, 1926). We do not believe that Paleosphaeronites was attached to the surface of a live trilobite, but it more likely utilized any available hard substrate for larval settlement (Fig. 2). The basal disc of the theca accommodates irregularities of the substrate, thus indicating loss of mobility during late ontogeny.

\section{Repository}

Barrande's types and specimens from Růžička's and Klouček's collections are stored in the palaeontological collection of the National Museum in Prague (NM L). The newly collected material is stored in the palaeontology collections of the University of West Bohemia, Plzeň (PCZCU).

\section{Systematic palaeontology}

Class Rhombifera Zittel, 1879

Superfamily Glyptocystitidacea Bather, 1899

Family Macrocystellidae Bather, 1899

\section{Genus Macrocystella Callaway, 1877}

Type species. - Macrocystella mariae Callaway, 1877; Shineton Shales, upper Tremadocian; Shropshire, England.

\section{Macrocystella cf. greylingi Hammann \& Sdzuy, 2001} Figures 2D, 3A-D

1984 Macrocystella? sp. - Mergl, p. 13.

1986 Macrocystella sp. - Mergl, p. 34.

1999 Macrocystella sp. - Prokop \& Petr, p. 64.

Material. - Five isolated thecal plates (PCZCU 1506, $1508,1509)$ and a cluster of thecal plates lacking details (PCZCU 1507).

Description. - The theca is known from five disarticulated, isolated, thin plates: one pentagonal plate, three hexagonal plates, and one plate with obscure, probably pentagonal outline are present in the collection. Thecal plate sizes range from 5 to $7 \mathrm{~mm}$. Inner and outer surfaces of the plates are smooth. The basal (B) plate (PCZCU 1506; Fig. 3B) is pentagonal in outline, its concave margin is raised and thickened. All plates bear prominent, sharp edged, ridge-like
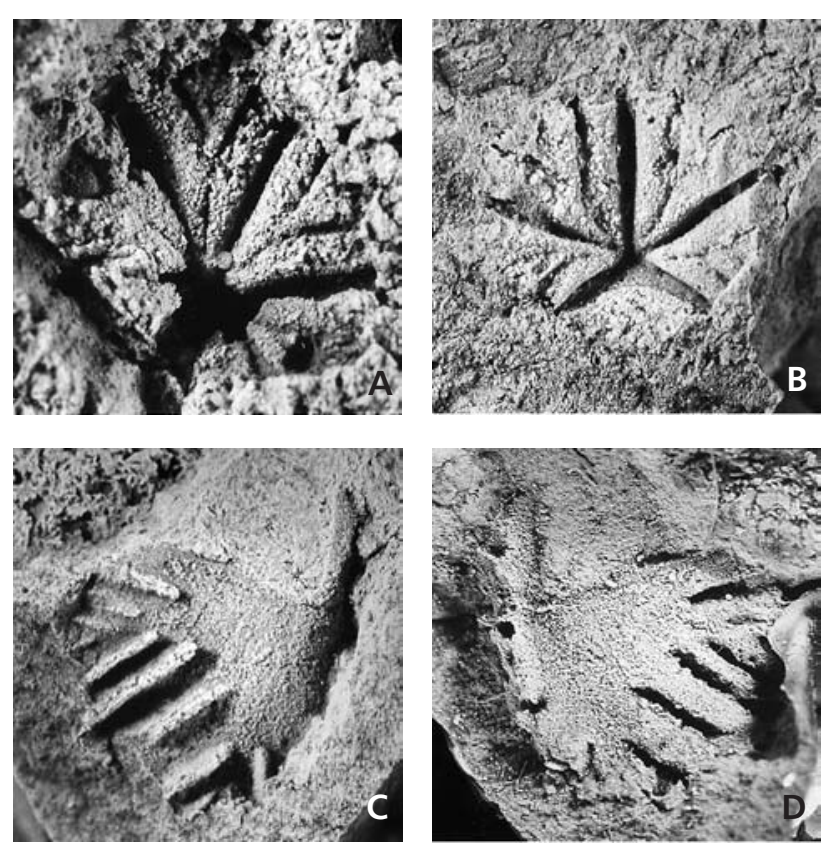

Figure 3. Macrocystella cf. greyilingi Hammann \& Sdzuy, 2001, Mílina Formation, locality Horní Kvaň. • A - external mould of plate, PCZCU 1509, x 5.5. • B - external mould of pentagonal plate, PCZCU $1506, x 5.5 . \cdot C, D-$ internal mould of plate and latex cast of the same plate, PCZCU 1508, x 5.5.

radiating primary folds, meeting in a prominent central boss. Intercalated accessory folds form one or two pairs between the primary folds. Large plates are distinctly asymmetric; the accessory folds are finer than the primary folds. Accessory folds are shorter than primary folds on the inner side of plate. Brachioles and stem columnals are unknown.

Remarks. - There are no obvious differences between the German specimens of M. greilingi Hammann \& Sdzuy, 2001 and the recently studied materials from the Mílina Formation. Sdzuy et al. (2001) commented extensively on the relationship of $M$. greilingi to other species, including the type species $M$. mariae Callaway, 1877 . The early Tremadocian species $M$. bavarica (Barrande, 1868) from the Leimitz Shales of Bavaria (Sdzuy 1955) differs from the typical Bavarian specimens of $M$. greilingi by more numerous accessory folds and by different outer flanges in the proximal columnals. The main differences between $M$. greilingi and M. mariae concern the shape of the outer proximal columnals (Paul 1968, Sdzuy et al. 2001), as the shapes of the thecal plates are almost identical. However, columnals are unknown in the Bohemian material, and therefore the relationships of $M$. cf. greylingi to $M$. bavarica as well as to $M$. mariae are difficult to evaluate.

Macrocystella Callaway, 1877 is a rhombiferan with a very wide stratigraphic distribution (late Cambrian to late Ordovician). An attribution of the Bohemian specimens to 

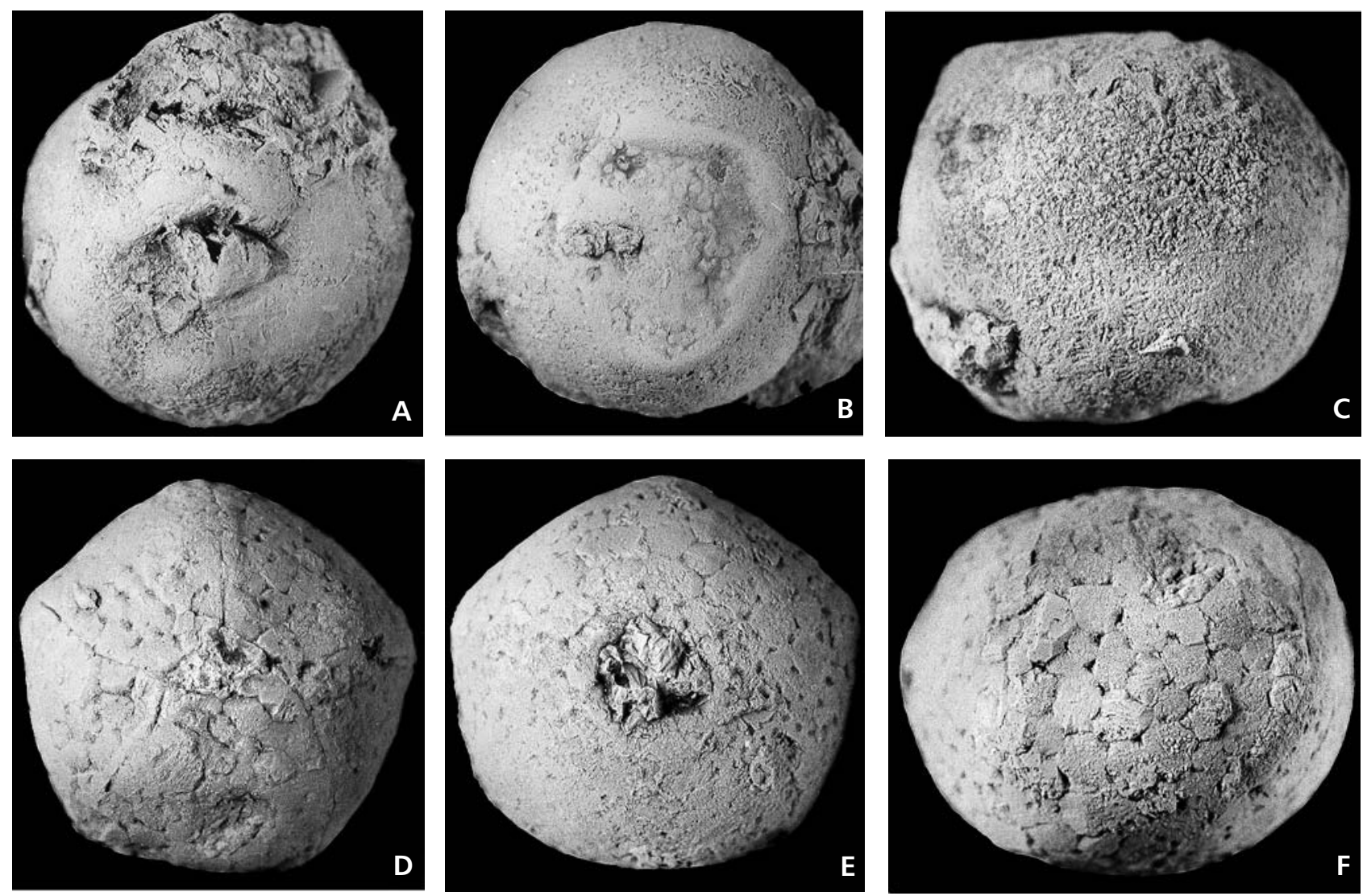

Figure 4. Echinosphaerites concomitans Barrande, 1887. Třenice Formation, locality Holoubkov, abandoned mine "V Ouzkém". Lectotype, internal mould of complete theca, peristomal area (A), adoral part (B), and size view (C), NM L 13111, x 3.0 (A, B), x 3.4 (C). Glyptosphaerites ferrigena (Barrande, 1887). Třenice Formation, locality Holoubkov, abandoned mine "V Ouzkém". Lectotype, internal mould of complete immature theca, peristomal area (D), adoral part (E), side view (F), NM L 10618, x 3.0 (D, E), x 3.4 (F).

Bavarian species confirms close relationship between the fauna of the Mílina Formation of Bohemia and the fauna of the Vogtendorf Formation of Bavaria. Both faunas are referred to the upper Tremadocian (Sdzuy et al. 2001). The approximate stratigraphic correlation of Lower Ordovician Bavarian and Bohemian units proposed by Vaněk (1965) and subsequently presented by Havlíček \& Vaněk (1966) has not been supported by any recent evidence. Despite the rarity and poor preservation of $M$. cf. greylingi in the Mílina Formation, both the morphology of its thecal plates and its stratigraphical level contradict the correlation with the overlying beds of the Mílina Formation (Jivinella slaviki Horizon of Havlíček \& Vaněk 1966; table 2) with the Macrocystella bavarica Zone of Bavaria. The Macrocystella bavarica Zone (Sdzuy 1955) is significantly older than the Vogtendorf fauna (Sdzuy et al. 2001). The presence of $M$. cf. greylingi in the Mílina Formation accounts for a late Tremadocian age for the early Ordovician fauna of the Prague Basin.

Occurrence. - Mílina Formation, beds with Jivinella incola; Prague Basin, Horní Kvaň; rare.
Superfamily Caryocystitidacea Jaekel, 1918

Family Echinosphaeritidae Neumayr, 1899

\section{Genus Echinosphaerites Wahlenberg, 1818}

Type species. - Echinus aurantium Gyllenhaal, 1772; Middle Ordovician; Sweden.

\section{Echinosphaerites concomitans Barrande, 1887}

Figures 2B, 4A-C, 5A-C

1887 Echinosph.? concomitans Barr; Barrande, p. 153, pl. 21, figs I/5-10, 12-14.

1999 Echinosphaerites? concomitans Barrande, 1887. Prokop \& Petr, p. 64.

Lectotype. - Internal mould of a complete theca of immature specimen figured by Barrande (1887, pl. 21, figs I/5-7) and refigured here on (Figs 4A-C, 5A), deposited in the collections of the National Museum, Prague (NM L 13111). 
Paralectotypes. - Fragment of theca figured by Barrande (1887, pl. 21, figs I/13, 14), refigured here on Fig. 6C (NM $\mathrm{L}$ 10620). A small thecal fragment figured by Barrande (1887, pl. 21, figs I/11, 12) (NM L 10621).

Material. - Apart from the type specimens, five small thecal fragments (NM L 38016, NM L 38010, other without number).

Description. - The lectotype represents a small theca (17.5 mm in diameter) of an immature specimen. It is almost globular, weakly depressed, with perfect circular outline and evenly convex sides. It lacks any pentagonal symmetry.

The theca of adult specimens is larger, approximately 25-40 $\mathrm{mm}$ in diameter (estimated after largest thecal plates known). Thecal plates are mostly hexagonal, rarely heptagonal or pentagonal, of similar size, almost regularly arranged over the theca. Small plates, usually subquadrate or irregularly polygonal, are rarely intercalated between plates of average size. Plates of the lectotype are 1.0-1.2 mm large, but the available fragments of larger specimens have 2 to $3 \mathrm{~mm}$ sized plates. Sutures are less distinct. Internal pores are located midway between the sutures and the centre of the plate. There are 5, 6, or 7 pores forming a somewhat irregular circle in each plate. Tangential canals form regular compound fistulipores in broad humatirhombs. There are only two to seven fistulipores in a rhomb in immature specimens (e.g., in the lectotype), and up to nine fistulipores per rhomb in large specimens. The radial internal fistulipores are generally thinner than the divergent marginal fistulipores. The peristome is elevated, forming a crescentic transverse ridge. The periproct rests on a broadly conical elevated part of the theca, close to the peristome. The base of the immature theca shows a large irregular area, probably a cicatrix reflecting cementation to a substrate or the thickening of the plates at the base of the theca. Epitheca is unknown.

Remarks. - The species belongs to the stratigraphically earliest report of Echinosphaerites Wahlenberg, 1818. The Bavarian species E. henkleini Hammann \& Sdzuy, 2001 is similarly sized; it has similar shape and size of plates. The number and arrangement of fistulipores are very similar to those of E. concomitans Barrande, 1887. Hammann \& Szduy (in Sdzuy et al. 2001) commented on their relationships, and noted the smaller size and less numerous fistulipores in humatirhombs in E. concomitans as the main difference. However, these differences are related to the small size, and probable immaturity of the type specimen of E. concomitans. There are two other differences between the adults of these species. Humatirhombs of E. henkleini are longer and the marginal fistulipores of adjacent humatirhombs are very near, leaving a very narrow septum-like wall between them; in E. concomi- tans adjacent marginal fistulipores diverge more toward the centre of the plate, leaving a narrowly triangular space between them. The central location of the internal pores of E. henkleini differs significantly from the more marginal arrangement of internal pores in E. concomitans. Despite these differences, the general morphology of the theca, and the size and shape of humatirhombs indicate a close affinity between these two species, and distinguish them from stratigraphically younger species. Numerous subspecies of E. aurantium (Gyllenhaal, 1772) and related Ordovician species from the Baltic area have more numerous and dispersed internal pores, and the sizes of their thecal plates are larger than those of E. concomitans.

Occurrence. - Třenice Formation, basal massive haematite; Prague Basin, locality Holoubkov, abandoned mine "V Ouzkém"; rare.

\section{Echinosphaerites sp.}

Figures 2F, 5D-H

\section{Echinosphaerites? sp. nov.; Klouček, p. 7.}

Material. - A complete theca of an immature specimen (NM L 13233a-c), and four fragments of thecae (NM L 13224, NM L 13225, NM L 13232, PCZCU 1510).

Description. - Theca is globular, $25 \mathrm{~mm}$ high though some thecal fragments indicate a slightly larger size. The basal part of the theca is extended into a short transverse ridge; stem junction is unknown. Large thecal plates are regularly hexagonal or less commonly heptagonal or pentagonal. Smaller plates are irregular. The theca consists of some $200-300$ plates of $2-3 \mathrm{~mm}$ size. The plates are almost flat externally and weakly concave internally. Narrow, shallow but distinct sutures are present on the external surface; sutures are obscured internally. Pores are arranged in regular simple rows along the periphery of a plate, very close to the sutures, encircling the plate. The sub-central part of the plate is without pores. The diameter of internal pores is uniform (cca $0.1 \mathrm{~mm}$ ). There are 4-5 perpendicular pores per $\mathrm{mm}$ at each row. Tangential canals (= fistulipores) are not preserved, but they must have been very short judging from the arrangement of the internal pores. A peristomal area is slightly elevated, with a small, transversely subpentagonal, elevated peristome; its details are unknown. Thecal plates adjacent to the peristome are thicker, with convex internal surfaces. In the internal mould of the peristome (Fig. 6F), a long wide left-turned canal extending from the mouth is preserved; it probably housed an oesophagus. The periproct is roundly pentagonal, and apparent 

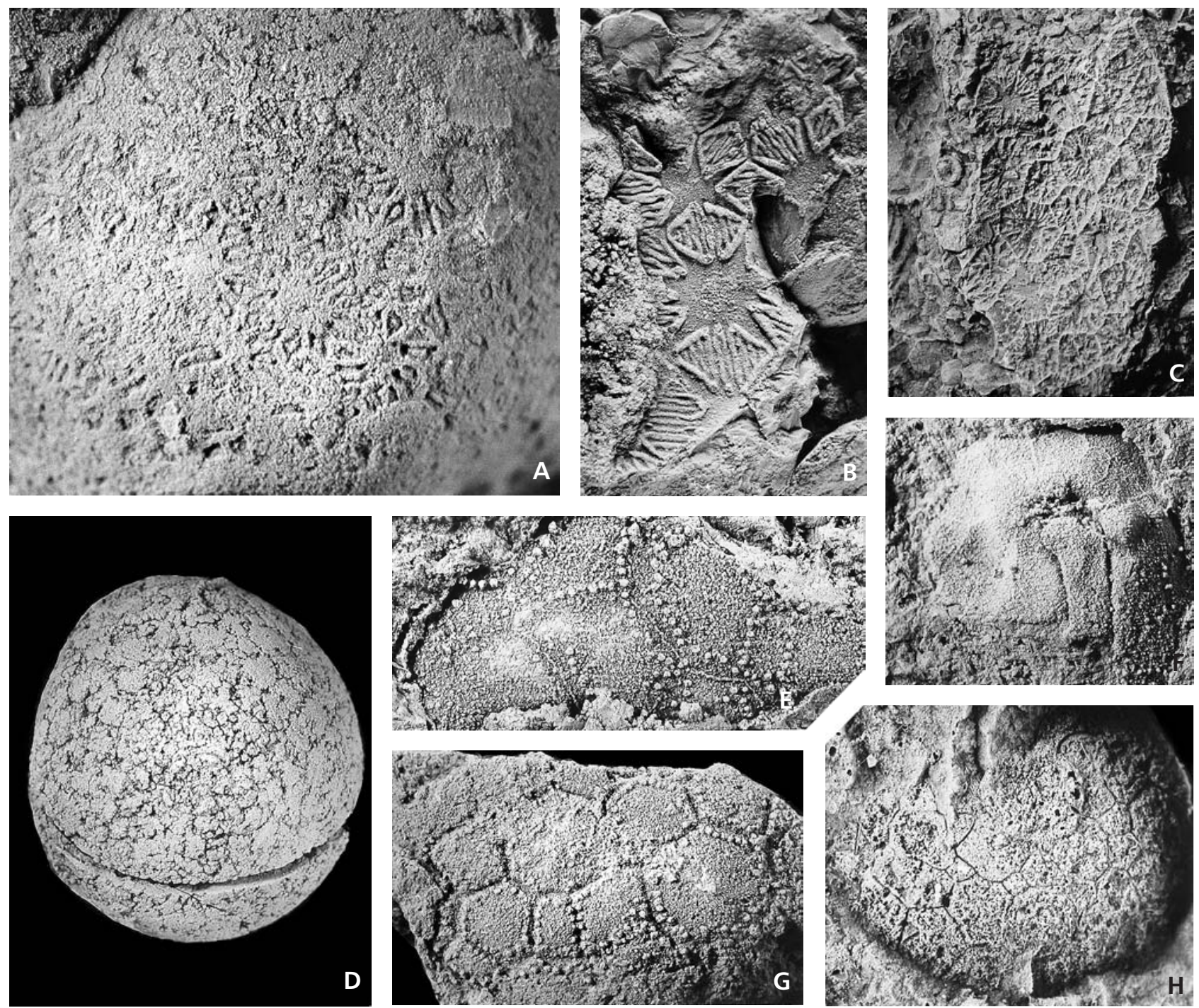

Figure 5. Echinosphaerites concomitans Barrande, 1887. Třenice Formation, Holoubkov, abandoned mine "V Ouzkém" (A-C). A - lectotype, detail of theca wall, NM L 13111, × 10.0. B - external mould showing humatirhombs, NM L 38016, × 10.0. $\bullet$ - paralectotype, external mould of thecal wall, NM L 10620, × 3.4. • Echinosphaerites sp. Mílina Formation, localities Olešná (D, E, G, H) and Horní Kvaň (F). D - complete theca, internal mould, NM L 13233a, b, $\times 2.2$. $\bullet$ E - fragment of theca, internal mould, NM L 13232a, b, $\times 5.5 . \bullet F-$ peristomal area, internal mould, PCZCU 1510, $\times 5.5$. $\cdot$ G fragment of theca, internal mould, NM L $13224 ; \times 5.5 \cdot \bullet \mathrm{H}-$ exterior of theca with periproct, latex cast of external mould, NM L $13225, \times 5.5$.

in the upper half of the theca near the peristome; its details are unknown.

Remarks. - The morphology of this species is different from that of other cystoids known from both the Třenice and Mílina formations. It is characterised by regular rows of internal pores near the periphery of plates, leaving a large area in the centre of plate without pores. The inferred length of the fistulipores is remarkably short (Fig. 5), and humatirhombs were probably very short and broad. This distinguishes the species from other species and subspecies of Echinosphaerites (Regnéll 1945, Paul 1972, Bockelie 1981) that have inner pores located more centrally in plates and show correspondingly longer fis- tulipores. The species E. concomitans Barrande, 1887 from the Třenice Formation has typical fistulipores in broad complex humatirhombs with only several inner pores in each plate. The upper Tremadocian E. henkleini Hammann \& Sdzuy, 2001 has less numerous inner pores near the centre of the plate. The species $E$. sp. represents a new species and possibly also a new genus (the arrangement of its pores featuring Arachnocystites Neumayr, 1889), but limited material makes the establishment of any new taxon premature.

Occurrence. - Mílina Formation, beds with Jivinella incola; Prague Basin, localities Horní Kvaň and Olešná; rare. 
Class Diploporita Müller, 1854

Superfamily Glyptosphaeritidacea Bernard, 1895

Family Glyptosphaeritidae Bernard, 1895

\section{Genus Glyptosphaerites Müller, 1854}

Type species. - Sphaeronites leuchtenbergi Volborth, 1846; Middle Ordovician; Russia.

\section{Glyptosphaerites ferrigena (Barrande, 1887)}

Figures 2A, 4D-F, 6A-H

1887 Echinosph.? ferrigena Barr; Barrande, p. 154, pl. 21, figs $\mathrm{I} / 1-4,9,10$.

1965 Glyptosphaerites ferrigena (Barrande, 1887). - Prokop, p. 807.

1999 Echinosphaerites? ferrigena Barrande, 1887. - Prokop \& Petr, p. 64

1999 Pyrocystites? sp. - Prokop \& Petr, p. 64.

Lectotype. - NM L 10618, complete theca of immature specimen, figured by Barrande (1887, pl. 21, figs I/1-4), and refigured here (Figs 4D-F), deposited in the collections of the National Museum, Prague.

Paralectotype. - Fragment of theca figured by Barrande (1887, pl. 21, fig. I/9), and refigured here on Fig. 6C, deposited in the collections of the National Museum in Prague (NM L 13113).

Material. - Apart from type specimens, six large (consisting of more than 50 plates) fragments of thecae (NM L 13220, NM L 13223, NM L 37999, PCZCU 1500a, b, 1501 ) and a few small (of less than 50 plates) thecal fragments (NM L 38014, PCZCU 1500c).

Description. - The lectotype represents a small theca (18 $\mathrm{mm}$ in diameter), probably of an immature specimen. It is almost globular, weakly depressed, with distinct pentagonal symmetry. The theca of adults is larger, with a diameter of $100 \mathrm{~mm}$ or more, subglobose, and made of several thousand plates. The inferred number of plates ranges between 2000 and 4000 (calculated from $10 \mathrm{~mm}^{2}$ sized average plates). The column is present in small immature specimens, with a shallow trace in adoral part near the column junction.

Judging from its preservation in coarse-grained sediment, the theca was rather solid and rigid. The thickness of the wall of a stereotheca is about $2 \mathrm{~mm}$ in the largest fragments. The thecal plates of stereotheca are polygonal, mostly pentagonal to octogonal, but smaller plates inserted between larger ones have rhomboidal, trapezoidal, or rectangular outlines. External surface of the plate is weakly and evenly convex, while the internal surface is gently arched near the centre of the plates. The largest plates measure cca 3-4 mm, but the most common size is only $2-3 \mathrm{~mm}$. The plates are irregularly arranged in the theca. Sutures are clearly defined. The surface of large plates bears fine, circular, regularly arranged shallow pits of uniform size. Thin epitheca consists of a thin small finely granulose layer, without distinct sutures between plates. Pores are variable in character, size, and arrangement over the different parts of the theca. Diplopores are small, lying at the bottom of a small shallow oval peripore. The size of peripores is uniform, approximately $1 \mathrm{~mm}$ long and $0.5 \mathrm{~mm}$ wide, without a raised periphery. The pore canals are Y-shaped, with a long, fused, perpendicular canal. A single larger circular pore is present on the inner surface of theca, corresponding to a diplopore on the external surface. The internal pores are uniformly $0.5 \mathrm{~mm}$ in diameter. The diplopores are radially arranged, forming an irregular simple circle along the plate periphery, but concentrated mostly on sutures and at the junction of three plates. Diplopores are only rarely present in the central part of plates. More or less clearly defined circlets of inner pore openings define the otherwise weak sutures between stereothecal plates on the internal surface of the theca.

The peristome is pentagonal, with long ambulacral grooves. Details of the peristome are unknown. One specimen shows weakly curved, long, and narrow branched ambulacral grooves with three short lateral branches (Fig. 7D, F) slightly elevated on the thecal surface. The observed distance of the distal ends of ambulacral grooves is $40 \mathrm{~mm}$. The lectotype has long, weakly arcuate ambulacral grooves extending from the small pentagonal peristome. The thecal surface near the distal parts of each ambulacral groove is weakly elevated above the remaining parts of theca, giving it a subpentagonal shape.

Remarks. - General morphology of the theca of Echinosphaerites? ferrigena Barrande, 1887 is consistent with Glyptosphaerites Müller, 1854. A large theca, radially arranged diplopores, and long, radial, shortly branched ambulacra are very similar to G. leuchtenbergi (Volborth, 1846). It is noticeable that some diplopores of G. leuchtenbergi are sectioned by suture. This feature, otherwise uncommon in G. leuchtenbergi (see Regnéll, 1945; p. 156, pl. 9, fig. 6), is typical in G. ferrigena. However, there are differences: diplopores in G. leuchtenbergi are much more numerous, arranged in several incomplete, adorally directed rows; and a single, complete circle of pores on sutures is present in G. ferrigena. Thecal plates of G. ferrigena are less uniformly sized, with numerous small intercalated plates between the large ones. The diplopores are less numerous, arranged in simple circlets concentrated on sutures. Smaller, more numerous, and less uniformly sized thecal plates indicate the less advanced nature of G. ferrigena relative to G. leuchtenbergi. This is in accordance with 

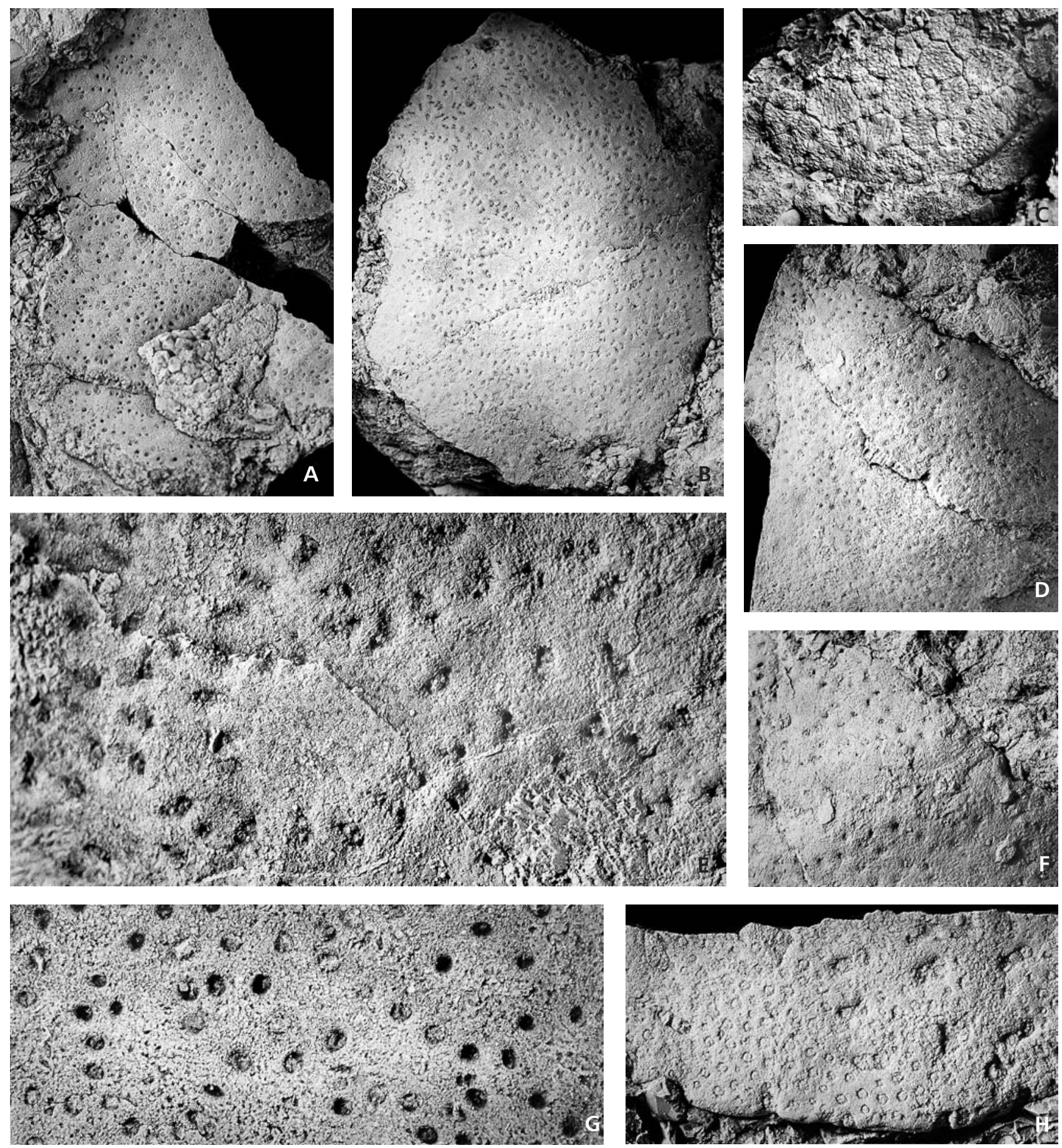

Figure 6. Glyptosphaerites ferrigena (Barrande, 1887). Třenice Formation, locality Holoubkov, abandoned mine "V Ouzkém". • A, G - inner side of stereotheca, showing irregular circles of inner pores (A) and circular openings of inner pores (G), PCZCU 1500b, $\times 1.6, \times 10.0$. $\bullet$ B, E - outer surface of stereotheca, showing circles of peripores (B) and arrangement of diplopores (E), NM L 37999, $\times 1.6, \times 10.0 \cdot \bullet$ - paralectotype, fragment of theca showing plates and epitheca, NM L 13113, $\times 3.4 \cdot \bullet$ D, F - outer surface of stereotheca showing distal part of ambulacrum in left upper side (D) and detail of branches of ambulacrum (F), PCZCU 1500a, $\times 1.6, \times 3.0 \cdot \bullet \mathrm{H}-$ fragment of stereothecal plate, showing diplopores and shallow circular pits on upper surface of the plate, NM L $38014, \times 10.0$.

younger stratigraphical position of the latter species. A large distorted theca of an aristocystitid diploporid reported from the Vogtendorf Formation of Bavaria (Sdzuy et al. 2001) has a different, more scattered arrangement of diplopores. Its peristomal area has a different organisation without long ambulacra. 

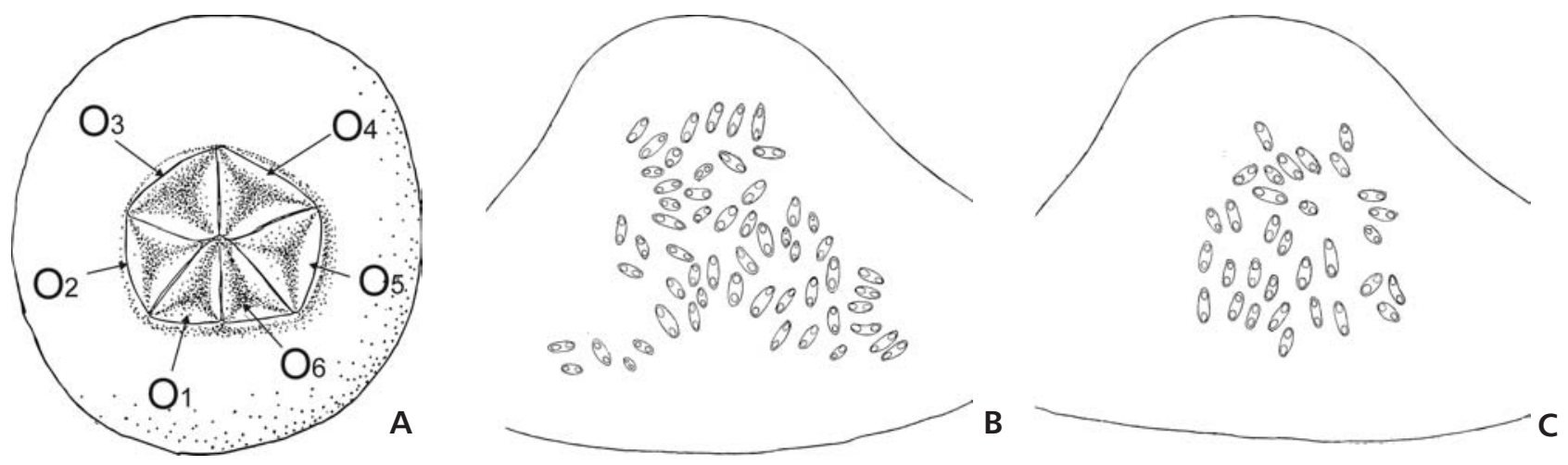

Figure 7. Paleosphaeronites crateriformis (Růžička, 1924). • A - reconstruction of oral cover plates, based on specimens NM L 16161 and NM L 16162. $\bullet \mathrm{B}, \mathrm{C}$ - distribution of diplopores and peripores in the slope of a conical theca in specimen NM L 5847.

Occurrence. - Třenice Formation, basal conglomerate beds with haematite cement; Prague Basin, locality Holoubkov, abandoned mine "V Ouzkém"; rare.

Family Sphaeronitidae Neumayr, 1889

\section{Genus Paleosphaeronites Prokop, 1964}

Type species. - Sphaeronites crateriformis Růžička, 1927; upper Tremadocian; Prague Basin; Bohemia.

Paleosphaeronites crateriformis (Růžička, 1927) Figures 2E, 7A-C, 8J-Q

1927 Sphaeronites crateriformis Růžička; Růžička, p. 12, pl. 2, figs $15-17$.

1927 Sphaeronites Batheri Růžička; Růžička, p. 12, pl. 2, figs 18-20.

1927 Sphaeronites sp.; Růžička, p. 13, pl. 2, fig. 21.

1964 Paleosphaeronites crateriformis (Růžička, 1927). Prokop, p. 10, pl. 1, figs 1-7.

1999 Paleosphaeronites crateriformis (Růžička, 1927). Prokop \& Petr, p. 64.

Lectotype. - Complete theca, figured by Růžička (1927, pl. 2, figs 15, 16), and refigured by Prokop (1964, pl. 1, figs 1,2 ), deposited in the collections of the National $\mathrm{Mu}-$ seum, Prague (NM L 5847).

Paralectotype. - Specimen figured by Růžička (1927, pl. 2, fig. 17), and refigured by Prokop (1964, pl. 1, fig. 3), deposited in the collections of the National Museum, Prague (NM L 5847).

Material. - Numerous and often complete but generally poorly preserved specimens (see Prokop 1964).

Description. - See Prokop (1964). Additional data about the peristome and pores are discussed here. The diplopores are unevenly scattered, with perpendicular canals $0.10-0.12 \mathrm{~mm}$ in diameter, and about $0.2 \mathrm{~mm}$ apart. Peripores are narrowly elliptical, long, and shallow, without raised periphery. The length of the peripore varies; some specimens have remarkably long peripores (e.g., NM L 5847), while in others they are distinctly shorter (e.g., NM L 5848). Their axes are arranged in irregular circles (tracing sutures ?) or directed toward the peristome (Fig. 5B).

The peristome is subpentagonal, transverse, weakly raised above the thecal surface. Ambulacral grooves on the thecal exterior are shallow and short. The peristome is small and covered by six palatals (Figs 7A, 8K, L), two of which are almost fused (O1, O6). Palatals have distinctly raised margins. Thin epitheca with numerous, uniformly

Figure 8. Paleosphaeronites grossularia sp. nov. Mílina Formation, locality Horní Kvaň (A, C-I) and Olešná (B). • A, E - holotype, complete theca, internal mould showing peristome, gonoduct, and anal pyramid, and the same specimen in lateral view (peristome right), PCZCU $1516, \mathrm{~A} \times 7.5, \mathrm{E} \times 7.65$. - B - complete theca, internal mould, NM L 38004, $\times 7.5 \cdot \bullet \mathrm{C}, \mathrm{H}-$ complete theca, internal mould showing peristome, gonoduct and anal pyramid, and the same specimen in oblique view (peristome left), PCZCU 1512, both $\mathrm{C} \times 7.5, \mathrm{H} \times 7.65$. $\bullet \mathrm{D}-$ complete theca, internal mould, $\mathrm{PCZCU} 1518, \times 8.85$. $\bullet \mathrm{F}-$ complete theca, latex cast of external mould showing peristome in upper part, PCZCU 1514, $\times 6.7$. $\bullet$ G, I - complete theca attached to trilobete exoskeleton, internal mould and latex cast of external mould, PCZCU 1513, both $\times 9.45$. Paleosphaeronites crateriformis (Růžička, 1927). Třenice Formation, locality Holoubkov, abandoned mine "V Ouzkém". • J, M - complete theca of large specimen in lateral and upper views, NM L 38000 , both $\times 2.2$. - $\mathrm{K}$ - peristome with four palatals, latex cast of external mould, NM L $16162, \times 7.65 . \bullet \mathrm{L}$ - peristome with six palatals, latex cast of external mould, NM L $16161, \times 7.65 . \bullet \mathrm{N}, \mathrm{Q}-$ small conical theca, and detail of peripores, NM L $5847, \times 5.5, \times 10.0 . \bullet \mathrm{O}-$ detail of complete theca, latex cast of external mould, showing diplopores and structure of epitheca, NM L 38006, $\times 7.65 \cdot \bullet P-$ detail of epitheca near attachement disc of theca, NM L $38012, \times 7.5$. 
Michal Mergl \& Rudolf J. Prokop • Lower Ordovician cystoids from the Prague Basin
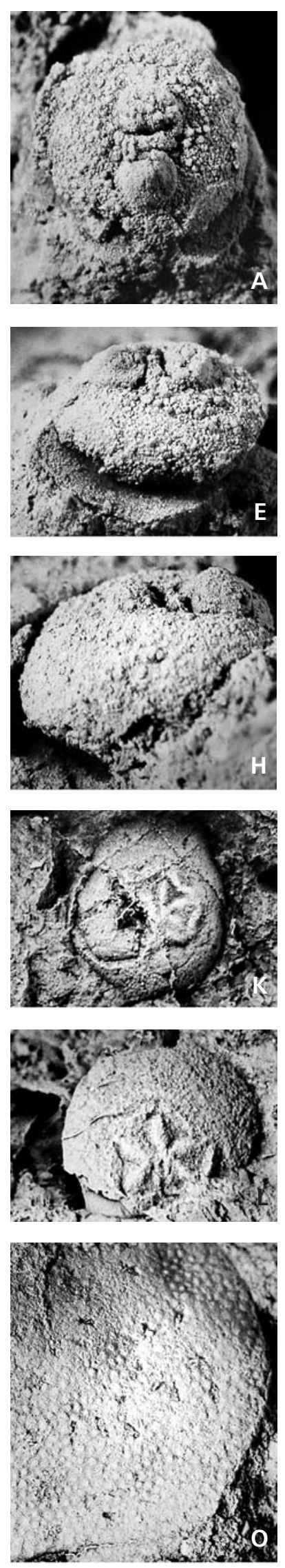
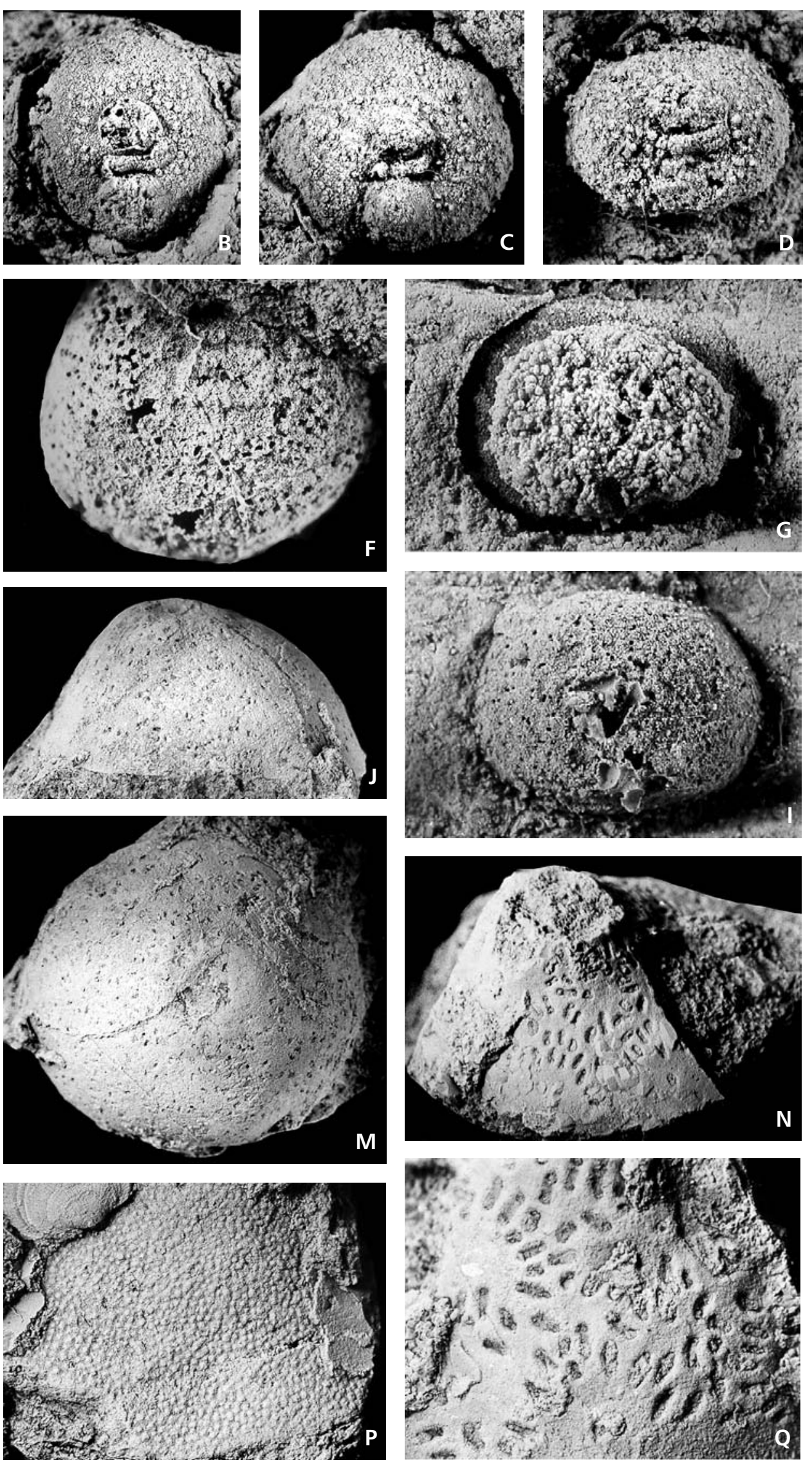
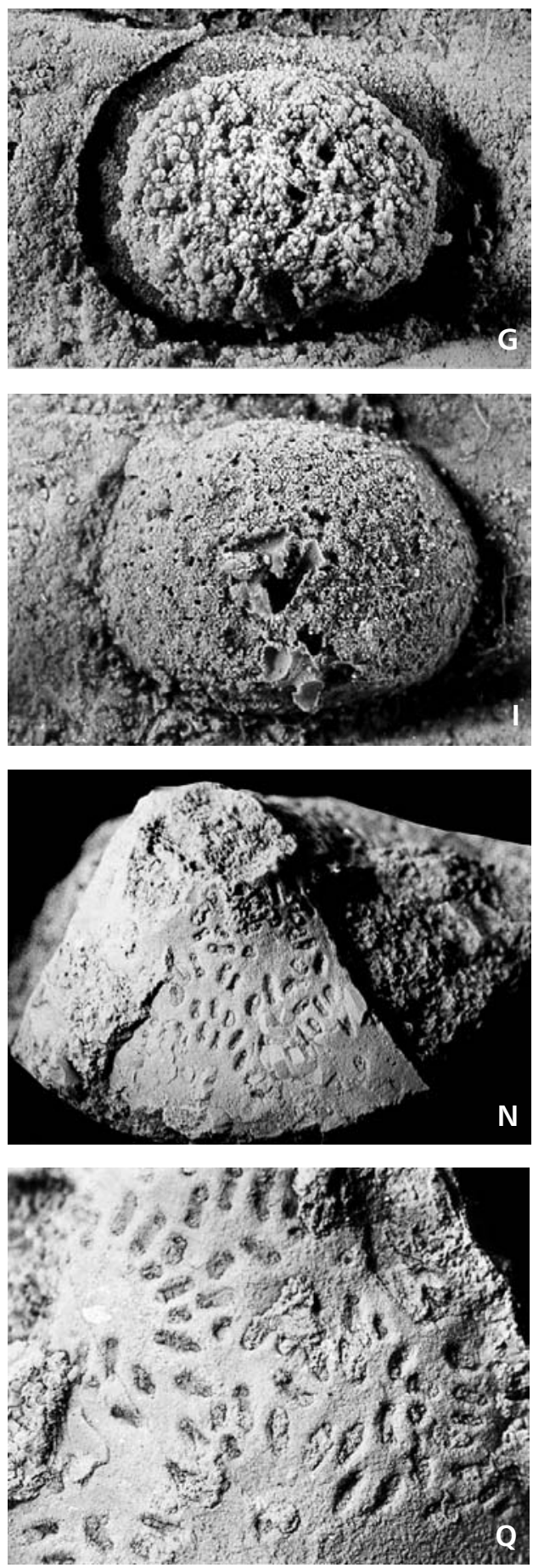


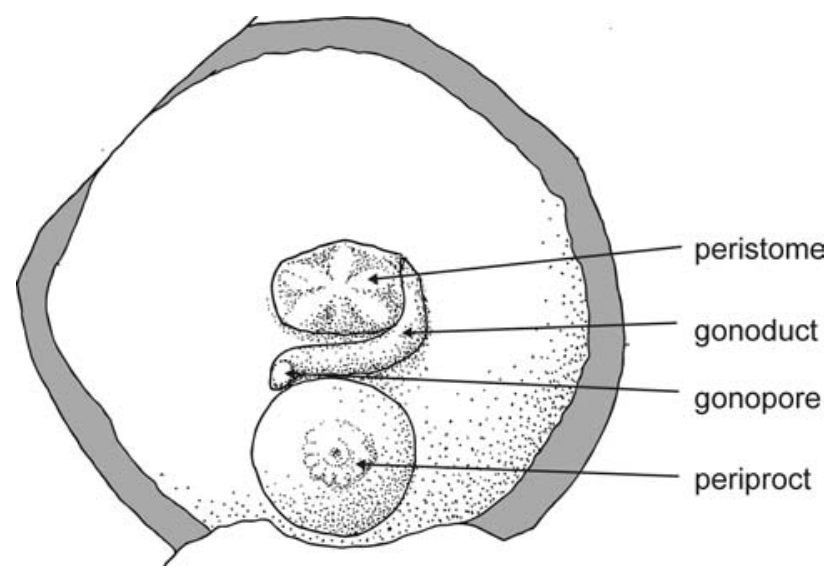

Figure 9. Paleosphaeronites grossularia sp. nov. Internal structures of theca showing the shape of the peristome, periproct, and gonadal tract. Based on internal mould, specimen PCZCU 1512. Original thecal wall is marked in grey.

sized $(0.1 \mathrm{~mm})$, small convex tubercles densely covering the entire thecal surface.

Remarks. - The largest specimens from the type locality measure $25 \mathrm{~mm}$ in diameter. The poorly preserved thecae referred to the same species from a greywacke near the Jivina locality are both of similar shape and size.

Occurrence. - Třenice Formation, basal conglomerate beds with haematite cement; Prague Basin, locality Holoubkov, abandoned mine "V Ouzkém"; abundant; locality Jivina, slope debris; rare.

\section{Paleosphaeronites grossularia sp. nov.} Figures 2G, 8A-I, 9

1984 Paleosphaeronites sp. - Mergl, p. 13.

1986 Paleosphaeronites sp. - Mergl, p. 34.

1999 Paleosphaeronites sp. - Prokop \& Petr, p. 64.

Holotype. - Complete theca, internal and external moulds of complete theca, figured on Fig. 8A, E deposited in the collections of the University of West Bohemia (PCZCU 1516).

Paratypes. - Four complete thecae, internal moulds (PCZCU 1512-1514, 1518).

Type horizon and locality. - Upper Tremadocian, Mílina Formation; Barrandian, Horní Kvaň.

Material. - Besides the types, three complete thecae (NM L 38003, NM L 38004, PCZCU 1515).
Diagnosis. - The new species is characterised by subglobose small theca (7-8 $\mathrm{mm}$ in diameter) with convex sides; it differs from $P$. crateriformis by its smaller, less elongate and more numerous peripores with the axis oriented toward the peristome.

Description. - The theca is depressed globose to mound-shaped, about twice as broad as it is high, subcircular to broadly oval in outline, with a flat base and evenly convex sides and adoral part. The diameter of the theca is no more than $6-8 \mathrm{~mm}$. The base of theca is attached directly to substrate by an evenly wide massive ring of fused plates. Sutures between plates forming the basal ring are not visible on any specimen. There are no plates inside the basal ring. The base accommodates to the substrate relief, as evinced by a specimen attached to a trilobite cranidium (Fig. 8G, I). Thickness of thecal plates rapidly decreases aborally; the basal ring is very massive, while lateral plates and these belonging to peristomal area are thin. Diplopores are unevenly scattered, absent in peristomal area, with perpendicular canals $0.10-0.12 \mathrm{~mm}$ in diameter, some $0.2 \mathrm{~mm}$ apart. Peripores are shallow, shortly oval; the fine details of their anatomy are unknown. The peristome is subpentagonal, transverse, weakly raised above the thecal surface. It is distinct internally as a deep transverse excavation with five short grooves in the thecal wall. Ambulacral grooves are shallow and short on the thecal exterior. The periproct is internally large, circular, with hexagonal symmetry, externally forming a small conical anal pyramid consisting of six plates. A narrow sinusoidal canal (preserved as mineral infilling) extends from the right side of the peristomal base and continues into an almost perpendicular canal to the thecal surface left of the area between the peristome and periproct (Figs 8A-D, 9). It is probably the trace of a gonoduct leading to a small gonopore left of the anal pyramid.

Remarks. - The difference between specimens from the Třenice and Mílina formations are slight, but they make it possible to assign the specimens from the Mílina Formation to a new species. There are two main differences between them. The thecal shape of $P$. crateriformis is always conical, with a wider base and straight, concave, or somewhat convex slopes (mainly in large specimens). The theca of $P$. grossularia sp. nov. is always subglobose, with evenly convex sides. The size of $P$. crateriformis is larger (up to $25 \mathrm{~mm}$ ) than that of $P$. grossularia sp. nov. (i.e., $7-8 \mathrm{~mm}$ ). Diplopores of $P$. grossularia are more numerous, with smaller peripores having an axis oriented toward the peristome. Peripores in P. crateriformis are generally longer and less regularly arranged.

Paleosphaeronites(?) prokopi Chauvel, 1966 is known from the upper Tremadocian (Lower Fezouata 

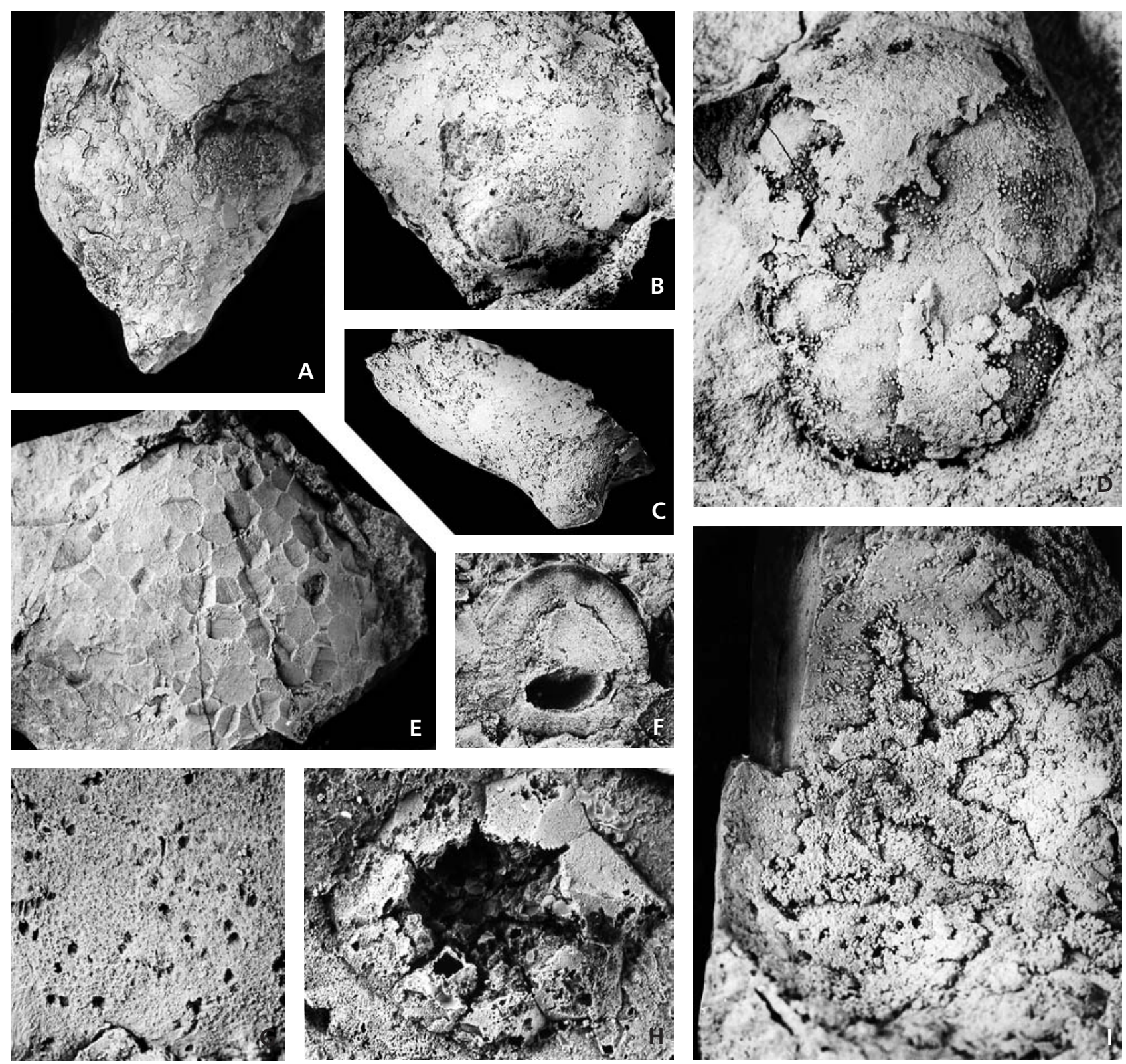

Figure 10. Pyrocystites sp. Třenice Formation, locality Holoubkov, abandoned mine "V Ouzkém”. • A - basal part of theca, internal mould, NM L $37997, \times 2.2$. E - part of theca, internal mould, NM L 37998, × 2.2. • F - Gen. indet, isolated columnalia, Třenice Formation, Holoubkov, latex cast of external mould, NM L 38015, x 7.5. • Pyrocystites sp. Mílina Formation, localities Olešná (B, C, G-I) and Horní Kvaň (D).• B, C, G - lower part of theca with short stalk, latex cast of external mould (B), side view (C) and detail showing diplopores in latex cast (G), NM L 13214, $\times 1.5, \times 1.5$, and $\times 7.5$. $\bullet-$ incomplete theca, internal mould, PCZCU 1503, × 1.5. Pyrocystites sp. Mílina Formation, localities Olešná (B, C, G-I) and Horní Kvaň (D). H - basal ring of eight plates attached to trilobite pygidium, NM L $38005, \times 6.7$. $・$ I - incomplete theca, external mould showing stellate structure, probably mineral cover of ambulacral grooves, NM L $38001, \times 1.5$.

Formation) of the Moroccan Anti-Atlas Mountains (Chauvel 1966). Part of a much larger theca referred to $P$.(?) cf. prokopi has subsequently been described and figured by Chauvel (1978) from the same region. Both forms are above the upper size limit of $P$. grossularia, and the density of their diplopores is much higher than in the new species. The thecal shape and its internal adoral morphology are remarkably similar to those of the stratigraphically earliest species of the genus
Sphaeronites Hisinger, 1828. The species Sphaeronites pomum (Gyllenhaal, 1772) and S. minor Paul \& Bockelie, 1983 (both from the "Arenigian" of Sweden) differ, apart from a different peristome area, by the presence of plates in the attachment area, which are lacking in $P$. grossularia sp. nov.

Occurrence. - Mílina Formation, beds with Jivinella incola; Prague Basin, localities Horní Kvaň and Olešná; rare. 
Family Gomphocystitidae Miller, 1889

\section{Genus Pyrocystites Barrande, 1887}

Type species. - Pyrocystites pirum Barrande, 1887; Middle Ordovician; Barrandian; Bohemia.

\section{Pyrocystites sp.}

Figure 2C, 10A-I

1917 Pyrocystites? n. sp. - Klouček, p. 7.

1927 Cystidea. - Růžička, p. 13, pl. 1, fig. 15.

1984 Glyptosphaeronites sp. - Mergl, p. 13.

1986 Glyptosphaerites sp. - Mergl, p. 34.

1999 Glyptosphaerites sp. - Prokop \& Petr, p. 64.

Material. - Four large fragments of theca (NM L 13214, NM L 38001, PCZCU 1503, 1504) and three small thecal fragments (NM L 38005, PCZCU 1504, 1505).

Description. - The thecae are large and inversely pearshaped, with convex sides $60-80 \mathrm{~mm}$ high, with rapidly tapering aboral parts. The base of theca was probably stalk-like and attached directly to the substrate. The stalk-like part consists of plates that are smaller than those in the rest of the theca. The large thecal plates, compared with thecal size, are rather thin (0.6 to $1 \mathrm{~mm})$, of irregular outline and flat surface. Sutures are obscure. Diplopores are irregularly arranged, scattered over the theca, they are commonly $0.5-0.6 \mathrm{~mm}$ long. Peripores are elongate, of variable length and depth. Pore canals are variable in arrangement. They are never fused proximally and, although mostly perpendicular to the plate surface, some are remarkably irregular, curved basally, and subtend a low angle to outer surface of the theca. The peristome is unknown; however, the stellate thick film of quartz on the external mould (Fig. 10I) may indicate the traces of ambulacral grooves. The large, circular, evenly convex periproct is located near the peristomal area.

Remarks. - The species is referred to the gomphocystitid genus Pyrocystites Barrande, 1887 based on its general thecal shape and the presence of diplopores. Pyrocystites pirum Barrande, 1887 (Šárka Formation, Middle Ordovician of the Barrandian area) has a similar thecal shape and long, weakly clockwise-arcuated ambulacra. However, the ambulacra of Pyrocystites sp. are unknown, and if the above-mentioned stellate film really covered the ambulacral grooves, they are shorter and less arcuated than in $P$. pirum (cf. Prokop 1964, pl. 1, fig. 8). Diplopores of Pyrocystites pirum are clustered in the centres of the thecal plates; this has not been observed in Pyrocystites sp. The periproct of $P$. pirum is large, circular, dome-shaped; a similar large circular structure, probably representing the anal pyramid, is present in one of our specimens. Circles of 8-9 plates attached to the surface of a trilobite shield (Fig. 10H) could belong to this species. Until more new material is available, the taxonomic position of the species will remain unclear.

Similar, poorly-preserved, inversely pear-shaped but recrystallized thecae are known from haematites of the Třenice Formation; one of them was figured by Růžička (1927, pl. 1, fig. 15). Although three specimens among the available material show a tapering stem-like extension that is unknown in all other cystoids from this locality, the insufficiency of other data including pores does not allow specific attribution of these remains.

Occurrence. - Třenice Formation, basal conglomerate beds with haematite cement; Prague Basin, locality Holoubkov, abandoned mine "V Ouzkém"; rare. Mílina Formation, beds with Jivinella incola; Prague Basin, locality Horní Kvaň; rare.

\section{Addendum}

Klouček (1918) reported, as possible organic remains, a find consisting of several mm long, subrectangular, thin plates in the red shales of the Svatá Dobrotivá area. New material was collected in the lower part of the Klabava Formation - the reddish Olešná Member (early Arenigian), some $4 \mathrm{~m}$ above the highest chert bed of the underlying Mílina Formation at the Zaječov locality (SW from Komárov), at approximately the same site as noted by Klouček (1918). A bed bearing these plates is a good local stratigraphical marker.

Klouček (1918) compared these problematic remains with plates of a polyplacophoran Helminthochiton aequivoca Robson, 1913; they are also reminiscent of isolated central plates of mitrates. Newly collected material from the same area, and examination of material in the old collection of the National Museum in Prague, both indicate that these remains more likely represent the imprints of mineral crystals, and thus are not organic in origin. They are always uniform in shape but of different sizes. Some of these imprints show the penetrational coalescence of crystals and traces of apposition growth. As the original material was always removed, the chemical composition of the corresponding mineral is unknown.

\section{Acknowledgements}

This research was supported by the Grant Agency of the Czech Republic grant 205/03/0670 "Fauna and Stratigraphy of the Tremadocian in Bohemia". It is a contribution to IGCP Project 503 "Ordovician Palaeogeography and Palaeoclimate". The authors would like to thank Petr Storch and Bertrand Lefebvre for their careful revisions of the manuscript. 


\section{References}

BARRANDE, J. 1887. Système silurien du centre de la Bohême. 7. Classe des Echinodermes, Ordre des Cystidées. XVII + 233 pp., 39 pls. Leipzig, Praha.

BoCKELIE, J.F. 1981. Functional morphology and evolution of the cystoid Echinosphaerites. Lethaia 14(3), 189-202.

BockeliE, J.F. 1984. The Diploporita of the Oslo region, Norway. Palaeontology 27(1), 1-68.

Chauvel, J. 1966. Echinodermes de l'Ordovicien du Maroc. $\mathrm{Ca}$ hiers de Paléontologie, Éditions du Centre National de la Recherche Scientifique, 1-120.

Chauvel, J. 1978. Compléments sur les Echinoderms du Paléozoïque marocain (Diploporites, Eocrinoïdes, Edrioasteroïdes). Notes du Service géologique du Maroc 39(272), 27-78.

Gutiérrez-Marco, J.C., Chauvel, J. \& Melénez, B. 1996. Neuvos equidermos (cystideos y blastozoos) del Ordovícico de la Cordillera Ibérica (NE Espana). Revista Española de Paleontología 11(1), 100-119.

HAVLÍČEK, V. 1977. Brachiopods of the order Orthida in Czechoslovakia. Rozpravy Ústředního ústavu geologického 44, 1-327.

HavlíčEK, V. 1982. Lingulacea, Paterinacea, and Siphonotretacea (Brachiopoda) in the Lower Ordovician sequence of Bohemia. Sborník geologických věd, Paleontologie 25, 9-82.

HAVLÍČEK, V. \& VANĚK, J. 1966. The Biostratigraphy of the Ordovician of Bohemia. Sborník geologických věd, Paleontologie 8, 7-69.

KETTNER, R. 1921. O transgresích a regresích spodnosilurského moře v Čechách. Rozpravy České akademie pro vědy, slovesnost a umění, Tř́da II 30(43), 1-7.

KLOUČEK, C. 1914. Nález trilobitů v $\mathrm{d}_{1 \alpha}$. Věstník Královské české společnosti nauk, Tř́la II 14, 1-5.

KLOUČEK, C. 1917. Novinky z krušnohorských vrstev d $d_{1 \alpha}$. Část II. Rozpravy České akademie pro vědy, slovesnost a umění, Tř́da II 26(10) , 1-7.

KLOUČEK, C. 1918. Novinky z krušnohorských vrstev d $\mathrm{d}_{1 \alpha}$. Část IV. Rozpravy České akademie pro vědy, slovesnost a umění, Tř́da II 28(38), 1-6.

LiPOLD, M.V. 1863. Die Eisensteinlager der Silurischen Grauwackenformation in Böhmen. Jahrbuch der Geologischen Reichsanstalt 13, 3 .
Mergl, M. 1984. Fauna of the Upper Tremadocian of central Bohemia. Sborník geologických věd, Paleontologie 26, 9-46.

Mergl, M. 1986. The Lower Ordovician (Tremadoc-Arenig) Leptembolon Community in the Komárov area (SW part of the Prague Basin; Bohemia). Folia Musei rerum naturalium Bohemiae occidentalis, Geologica 24, 1-34.

Mergl, M. 1994. Trilobite fauna from the Třenice Formation (Tremadoc) in Central Bohemia. Folia Musei rerum naturalium Bohemiae occidentalis, Geologica 39, 1-31.

Mergl, M. 2002. Linguliformean and craniiformean brachiopods of the Ordovician (Třenice to Dobrotivá Formations) of the Barrandian, Bohemia. Acta Musei nationalis Pragae, series $B$ - historia naturalis 58(1-2), 1-82.

PAUL, C.R.C. 1968. Macrocystella Callaway, the earliest glyptocystitid cystoid. Palaeontology 11(4), 580-600.

PAUL, C.R.C. 1972. Morphology and function of exothecal pore-structures in cystoids. Palaeontology 15(1), 1-28.

PaUL, C.R.C. 1973. British Ordovician cystoids. Monographs of the Palaeontographical Society 1, 1-64.

PAUL, C.R.C. \& BOCKELIE, J.F. 1983. Evolution and functional morphology of the cystoid Sphaeronites in Britain and Scandinavia. Palaeontology 26(4), 687-734.

PROKOP, R. 1964. Sphaeronitoidea Neumayr of the Lower Paleozoic of Bohemia. Sborník geologických věd, Paleontologie 3, 7-37.

Prokop, R.J. (= Prokop, R.) \& PetR, V. 1999. Echinoderms in the Bohemian Ordovician. Journal of the Czech Geological Society 44(1-2), 63-68.

RegnéLl, G. 1945. Non-crinoid Pelmatozoa from the Paleozoic of Sweden. A taxonomic study. Meddelanden fran Lunds geologisk-mineralogiska Institution 108, 1-255.

RƯŽIČKA, R. 1927. Fauna vrstev Eulomových rudního ložiska u Holoubkova (V Ouzkém). Č́st II. Rozpravy České akademie pro vědy, slovesnost a umění, Tř́da II 36(60), 1-21.

SDZuY, K. 1955. Cystoideen aus den Leimitz Schiefer (Tremadoc). Senckenbergiana lethaea 35(5-6), 269-278.

Sdzuy, K., Hammann, W. \& Villas, E. 2001. The Upper Tremadoc fauna from Vogtendorf and the Bavarian Ordovician of the Frankenwald (Germany). Senckenbergiana lethaea 81(1), 207-261.

VANĚK, J. 1965. Die Trilobiten des mittelböhmischen Tremadoc. Senckenbergiana lethaea 46(4-6), 263-308. 